Bangladesh J. Sci. Ind. Res. 41(1-2), 33-40, 2006

\title{
Response of Nitrogen and Phosphorus Fertilizer and Plant Spacing on Growth and Yield Contributing Character of Sunflower
}

\author{
A. A. Jahangir, R. K. Mondal, Katrun Nada, R. Sadia Afroze and M. A. Hakim \\ BCSIR Laboratories, Dhanmondi, Dhaka-1205. Bangladesh
}

\begin{abstract}
The plant spacing of 20, 25 and $30 \mathrm{~cm}$ were used for the study. The doses of nitrogen and phosphorus were 80, 100, 120 and 45, 60, $75 \mathrm{~kg} /$ hectare respectively. The experiment was carried out in a randomized block design with three replications. $20 \mathrm{~cm}$ plant spacing produced the highest plot yield. Maximum number of seeds per head and yield were produced by the application of $120 \mathrm{~kg} \mathrm{~N}+75 \mathrm{~kg} \mathrm{P}_{2} \mathrm{O}_{5}$ per hectare. In case of plant spacing $x$ fertilizer interaction effect, $20 \mathrm{~cm}$ plant spacing with $120 \mathrm{~kg} \mathrm{~N}+75 \mathrm{~kg} \mathrm{P}_{2} \mathrm{O}_{5}$ per hectare treatment produced the highest head diameter and seed yield.
\end{abstract}

\section{Introduction}

Sunflower (Helianthus annus L.) is relatively proved a good oil seed crop in Bangladesh. It is a potential source of high quality edible oil, ranges second next to soybean as an oil crop in the world (FAO). ${ }^{1}$ Due to the increasing edible use of this oil crop, its production has been enhanced rapidly all over the world. Sunflower's seed contains $48 \%-52 \%$ of good quality edible oil and $40 \%-50 \%$ of protein in meals. The oil cake from sunflower is also useful for cow and fish feeding. At present, sunflower is grown in many district of Bangladesh without proper care. The average production of sunflower per unit area in our country is comparatively poor. ${ }^{2}$ The total cultivation area of this particular oil crop is limited. The progress in sunflower production is slow due to the lack of proper production technologies and management practices. Among the several agro-techniques which can enhance the production of yield are the use of proper land preparation, irrigation, fertilizer application, proper plant spacing and other related factors are important. Robinson et al., Reddy et al. and Villalobos et al. assessed that better seed yield of sunflower was greatly influenced by proper plant spacing. ${ }^{3-5}$ According to Kharga et al., Sharma et al. and Vivck et al., nitrogen fertilizer has a positive effect on sunflower yield. ${ }^{6-8}$ Several authors observed that the application of nitrogen fertilizer in conjugation with phosphorus fertilizer resulted in increased seed yield of sunflower. ${ }^{9-11}$ (Chariara et al., Singh et al. and Ujjinaiah et al.). The information regarding the effect of 
plant spacing and nitrogen-phosphorus fertilizer on sunflower is mearge in our local climate condition. So, an attempt has been made to study the effect of plant spacing and nitrogen-phosphorus fertilizer for getting maximum yield of sunflower.

\section{Materials and Methods}

The investigation was made in the experimental field of BCSIR (Bangladesh Council of Scientific and Industrial Research) Dhaka, during the winter season of 2002-2003. The soil of the experimental field was sandy clay loam having $\mathrm{pH}$ 5.8, $1.5 \%$ organic matter and $0.04 \%$ total nitrogen. The $\mathrm{pH}$ of moist soil was determined by using a corning glass electrode $\mathrm{pH}$ meter (model-7). ${ }^{12}$ Organic matter content was calculated by multiplying the rules of organic carbon with conventional factor $1.74 .{ }^{13}$ The total nitrogen were determine Microkjeldahl method as described by Jakson. ${ }^{12}$ The unit plot size was $3 \mathrm{~m} \times 3 \mathrm{~m}$. The variety used for the study was Kironi. The experiment was carried out in a randomized block design with three replications.

The row spacing was $30 \mathrm{~m}$. The plant spacing of 20,25 and $30 \mathrm{~cm}$ were used for study.
The nitrogen fertilizer doses under study were $80 \mathrm{~kg} \mathrm{~N} / \mathrm{ha}\left(\mathrm{N}_{1}\right), 100 \mathrm{~kg} \mathrm{~N} / \mathrm{ha}\left(\mathrm{N}_{2}\right), 120$ $\mathrm{kg} \mathrm{N} / \mathrm{ha}\left(\mathrm{N}_{3}\right)$ and that of phosphorus $45 \mathrm{~kg}$ $\mathrm{P}_{2} \mathrm{O}_{5} /$ ha $\left(\mathrm{P}_{1}\right), 60 \mathrm{~kg} \mathrm{P}_{2} \mathrm{O}_{5} / \mathrm{ha}\left(\mathrm{P}_{2}\right), 75 \mathrm{~kg}$ $\mathrm{P}_{2} \mathrm{O}_{5} /$ ha $\left(\mathrm{P}_{3}\right)$. The sources of nitrogen and phosphorus were urea and triple super phosphate respectively. At the time of land preparation, nitrogen and phosphorus were applied in the soil and nitrogen was applied to the field in two equal installments. All the intercultural operation were done in proper time. At the harvest time, 10 plants were selected at random from each plot to collect data on plant height and different yield contributing characters. Yield was recorded from the plot. The collected data was statistically analyzed and mean values were adjudged by Ducan's New Multiple Range Test (Steel and Torrie). ${ }^{14}$

\section{Results and Discussion}

The data on the effect plant spacing and nitrogen - phosphorus fertilizer and their interaction have been presented in the Table I, II and III, respectively.

Table I. Effect of plant spacing on the yield contributing character of sunflower.

\begin{tabular}{c|c|c|c|c|c}
\hline $\begin{array}{c}\text { Plant spacing } \\
(\mathrm{cm})\end{array}$ & $\begin{array}{c}\text { Plant height } \\
(\mathrm{cm})\end{array}$ & $\begin{array}{c}\text { Head diameter } \\
(\mathrm{cm})\end{array}$ & $\begin{array}{c}\text { Number of } \\
\text { seed per head }\end{array}$ & $\begin{array}{c}100 \text { seed } \\
\text { weight }(\mathrm{g})\end{array}$ & $\begin{array}{c}\text { Seed yield } \\
(\mathrm{t} / \mathrm{ha})\end{array}$ \\
\hline 20 & $50.1 \mathrm{c}^{*}$ & $13.4 \mathrm{a}$ & $303.4 \mathrm{a}$ & $5.31 \mathrm{a}$ & $1.96 \mathrm{a}$ \\
25 & $57.8 \mathrm{~b}$ & $12.5 \mathrm{ab}$ & $290.3 \mathrm{~b}$ & $5.34 \mathrm{a}$ & $1.68 \mathrm{~b}$ \\
30 & $60.8 \mathrm{a}$ & $12.0 \mathrm{~b}$ & $289.4 \mathrm{~b}$ & $5.33 \mathrm{a}$ & $1.56 \mathrm{~b}$ \\
\hline
\end{tabular}

\footnotetext{
* Means with the same letter are not different from one another at $5 \%$ level of significance.
} 
Table II. Effect of nitrogen-phosphorus fertilizer on the yield contributing charcter of sunflower.

\begin{tabular}{c|c|c|c|c|c}
\hline $\begin{array}{c}\text { Nitrogen- Phos- } \\
\text { phorus fertilizer }\end{array}$ & $\begin{array}{c}\text { Plant height } \\
(\mathrm{cm})\end{array}$ & $\begin{array}{c}\text { Head diameter } \\
(\mathrm{cm})\end{array}$ & $\begin{array}{c}\text { Number of } \\
\text { seed per head }\end{array}$ & $\begin{array}{c}100 \text { seed } \\
\text { weight }(\mathrm{g})\end{array}$ & $\begin{array}{c}\text { Seed yield } \\
(\mathrm{t} / \mathrm{ha})\end{array}$ \\
\hline Control & $49.6 \mathrm{e}$ & $9.7 \mathrm{a}$ & $261.3 \mathrm{e}$ & $5.01 \mathrm{c}$ & $1.78 \mathrm{~b}$ \\
$\mathrm{~N}_{1} \mathrm{P}_{1}$ & $51.2 \mathrm{~d}$ & $10.2 \mathrm{a}$ & $280.3 \mathrm{~cd}$ & $5.39 \mathrm{abc}$ & $1.80 \mathrm{~b}$ \\
$\mathrm{~N}_{1} \mathrm{P}_{2}$ & $53.3 \mathrm{~cd}$ & $10.3 \mathrm{a}$ & $271.6 \mathrm{de}$ & $5.38 \mathrm{abc}$ & $1.81 \mathrm{ab}$ \\
$\mathrm{N}_{1} \mathrm{P}_{3}$ & $58.5 \mathrm{ab}$ & $10.1 \mathrm{a}$ & $273.2 \mathrm{de}$ & $5.39 \mathrm{abc}$ & $1.82 \mathrm{ab}$ \\
$\mathrm{N}_{2} \mathrm{P}_{1}$ & $59.0 \mathrm{ab}$ & $12.4 \mathrm{ab}$ & $280.4 \mathrm{~cd}$ & $5.60 \mathrm{ab}$ & $1.83 \mathrm{ab}$ \\
$\mathrm{N}_{2} \mathrm{P}_{2}$ & $58.2 \mathrm{ab}$ & $11.4 \mathrm{~b}$ & $285.8 \mathrm{c}$ & $5.36 \mathrm{abc}$ & $1.97 \mathrm{ab}$ \\
$\mathrm{N}_{2} \mathrm{P}_{3}$ & $59.0 \mathrm{ab}$ & $12.4 \mathrm{ab}$ & $313.2 \mathrm{~b}$ & $5.60 \mathrm{ab}$ & $1.86 \mathrm{ab}$ \\
$\mathrm{N}_{3} \mathrm{P}_{1}$ & $59.1 \mathrm{ab}$ & $12.7 \mathrm{a}$ & $314.8 \mathrm{~b}$ & $5.61 \mathrm{ab}$ & $1.97 \mathrm{ab}$ \\
$\mathrm{N}_{3} \mathrm{P}_{2}$ & $62.1 \mathrm{a}$ & $13.3 \mathrm{a}$ & $337.5 \mathrm{a}$ & $5.73 \mathrm{a}$ & $2.01 \mathrm{ab}$ \\
$\mathrm{N}_{3} \mathrm{P}_{3}$ & $61.7 \mathrm{ab}$ & $13.2 \mathrm{a}$ & $339.8 \mathrm{a}$ & $5.73 \mathrm{a}$ & $2.08 \mathrm{a}$ \\
\hline
\end{tabular}

* Means with the same letter are not different from one another at $5 \%$ level of significance.

\section{Plant Spacing Effect}

The plant height of sunflower increased progressively with the increase of plant spacing. The widest plant spacing produced the highest plant height $(60.8 \mathrm{~cm})$ among other spacing. It was significantly different from other treatments. The results were in agreement with the result of Bindra and Kharwara who found increased plant height with increase of spacing. ${ }^{15}$ They observed the same spacing of $30 \mathrm{~cm}$ in the case of plant height of sunflower. The lowest highest (50.1 $\mathrm{cm}$ ) plant was obtained from $20 \mathrm{~cm}$ plant spacing treatment. The plant grown with closer spacing produced maximum head diameter and the highest number of seeds than of those other spacing. The variation in plant spacing caused a significant difference in sunflower seed yield. The highest seed yield of $1.96 \mathrm{t} / \mathrm{ha}$ was recorded from $20 \mathrm{~cm}$ plant spacing. The highest and lowest yield were $1.96 \mathrm{t} / \mathrm{ha}$ and $1.65 \mathrm{t} / \mathrm{ha}$ respectively. The positive effect of closer plant spacing on seed yield as obtained in the present study agreed well to the findings of Islam et al. and Zaffaroni et al. where they found highest yield at closer plant spacing. ${ }^{16-17}$ Rao et al. also reported the reduction in sunflower yield under higher plant density. ${ }^{18}$ The other two plant spacing treatment produced near about the same seed yield without any significant change.

\section{Nitrogen - Phosphorous Fertilizer Effect}

In fertilizer treatment the maximum plant height $\left(62.1 \mathrm{~cm}\right.$.) was obtained by $\mathrm{N}_{3} \mathrm{P}_{2}$. The second highest plant height was resulted from $\mathrm{N}_{3} \mathrm{P}_{3}$ treatment. This was closely 
Table III. Interaction effect of plant spacing and fertilizer on the yield of sunflower.

\begin{tabular}{|c|c|c|c|c|c|c|}
\hline \multicolumn{2}{|c|}{$\begin{array}{l}\text { Plant spacing x N-P } \\
\text { fertilizer treatment }\end{array}$} & $\begin{array}{l}\text { Plant height } \\
\text { (cm) }\end{array}$ & $\begin{array}{l}\text { Head } \\
\text { diameter } \\
(\mathrm{cm})\end{array}$ & $\begin{array}{l}\text { Number of } \\
\text { seeds per } \\
\text { head }\end{array}$ & $\begin{array}{c}100 \text { seed } \\
\text { weight (g) }\end{array}$ & $\begin{array}{c}\text { Seed yield } \\
\text { (t/ha) }\end{array}$ \\
\hline \multirow{10}{*}{$20 \mathrm{~cm}$} & Control & $53.3 c^{*}$ & $11.8 \mathrm{c}$ & $265.2 \mathrm{e}$ & $4.99 \mathrm{f}$ & $1.91 \mathrm{c}$ \\
\hline & $\mathrm{N}_{1} \mathrm{P}_{1}$ & 54.5 bc & $13.4 \mathrm{ab}$ & $329.1 \mathrm{ab}$ & $5.58 \mathrm{~b}$ & 2.16 bc \\
\hline & $\mathrm{N}_{1} \mathrm{P}_{2}$ & 54.5 bc & $13.5 \mathrm{~b}$ & 339.1 a & $5.78 \mathrm{~b}$ & 2.16 bc \\
\hline & $\mathrm{N}_{1} \mathrm{P}_{3}$ & 54.3 bc & $13.5 \mathrm{~b}$ & $328.1 \mathrm{ab}$ & $5.67 \mathrm{~b}$ & $2.38 \mathrm{ab}$ \\
\hline & $\mathrm{N}_{2} \mathrm{P}_{1}$ & 54.4 bc & $14.2 \mathrm{ab}$ & $317.7 \mathrm{~b}$ & $5.67 \mathrm{~b}$ & $2.32 \mathrm{ab}$ \\
\hline & $\mathrm{N}_{2} \mathrm{P}_{2}$ & 60.7 abc & $13.7 \mathrm{ab}$ & 329.6 ab & $5.68 \mathrm{~b}$ & $2.40 \mathrm{ab}$ \\
\hline & $\mathrm{N}_{2} \mathrm{P}_{3}$ & 59.9 abc & $14.3 \mathrm{ab}$ & $317.8 \mathrm{~b}$ & $5.74 \mathrm{ab}$ & $2.30 \mathrm{ab}$ \\
\hline & $\mathrm{N}_{3} \mathrm{P}_{1}$ & $60.2 \mathrm{abc}$ & $14.4 \mathrm{a}$ & $340.1 \mathrm{a}$ & $5.66 \mathrm{~b}$ & $2.41 \mathrm{ab}$ \\
\hline & $\mathrm{N}_{3} \mathrm{P}_{2}$ & $62.1 \mathrm{ab}$ & $14.4 \mathrm{a}$ & 340.9 a & $5.67 \mathrm{~b}$ & $2.50 \mathrm{a}$ \\
\hline & $\mathrm{N}_{3} \mathrm{P}_{3}$ & 59.9 abc & $14.5 \mathrm{a}$ & $329.4 \mathrm{ab}$ & $5.63 \mathrm{~b}$ & $2.55 \mathrm{a}$ \\
\hline \multirow{9}{*}{$25 \mathrm{~cm}$} & $\mathrm{~N}_{1} \mathrm{P}_{1}$ & $60.1 \mathrm{abc}$ & $13.4 \mathrm{~b}$ & $318.2 \mathrm{~b}$ & $5.58 \mathrm{~b}$ & $2.32 \mathrm{ab}$ \\
\hline & $\mathrm{N}_{1} \mathrm{P}_{2}$ & 59.8 abc & $13.5 \mathrm{~b}$ & $318.1 \mathrm{~b}$ & $5.57 \mathrm{~b}$ & $2.30 \mathrm{ab}$ \\
\hline & $\mathrm{N}_{1} \mathrm{P}_{3}$ & 54.4 bc & $13.7 \mathrm{ab}$ & $317.9 \mathrm{~b}$ & $5.63 \mathrm{~b}$ & 2.17 bc \\
\hline & $\mathrm{N}_{2} \mathrm{P}_{1}$ & 59.9 abc & $13.7 \mathrm{ab}$ & $328.0 \mathrm{ab}$ & $5.69 \mathrm{~b}$ & 2.16 bc \\
\hline & $\mathrm{N}_{2} \mathrm{P}_{2}$ & $62.0 \mathrm{ab}$ & $13.5 \mathrm{~b}$ & $329.5 \mathrm{ab}$ & $5.67 \mathrm{~b}$ & $2.39 \mathrm{ab}$ \\
\hline & $\mathrm{N}_{2} \mathrm{P}_{3}$ & $61.9 \mathrm{ab}$ & $13.8 \mathrm{ab}$ & $317.5 \mathrm{~b}$ & $5.68 \mathrm{~b}$ & $2.18 \mathrm{ab}$ \\
\hline & $\mathrm{N}_{3} \mathrm{P}_{1}$ & $62.0 \mathrm{ab}$ & $13.7 \mathrm{ab}$ & $317.6 \mathrm{~b}$ & $5.78 \mathrm{a}$ & $2.32 \mathrm{ab}$ \\
\hline & $\mathrm{N}_{3} \mathrm{P}_{2}$ & $62.1 \mathrm{ab}$ & $14.2 \mathrm{ab}$ & 314.8 b & $5.80 \mathrm{a}$ & $2.32 \mathrm{ab}$ \\
\hline & $\mathrm{N}_{3} \mathrm{P}_{3}$ & $62.2 \mathrm{ab}$ & $14.2 \mathrm{ab}$ & $317.3 \mathrm{~b}$ & $5.59 \mathrm{~b}$ & $2.37 \mathrm{ab}$ \\
\hline \multirow{9}{*}{$30 \mathrm{~cm}$} & $\mathrm{~N}_{1} \mathrm{P}_{1}$ & $61.9 \mathrm{ab}$ & $11.8 \mathrm{c}$ & $281.1 \mathrm{~cd}$ & $5.22 \mathrm{de}$ & $1.95 \mathrm{c}$ \\
\hline & $\mathrm{N}_{1} \mathrm{P}_{2}$ & $62.2 \mathrm{ab}$ & 11.9 c & $279.9 \mathrm{~cd}$ & 5.07 ef & $1.97 \mathrm{c}$ \\
\hline & $\mathrm{N}_{1} \mathrm{P}_{3}$ & $60.1 \mathrm{abc}$ & $12.2 \mathrm{bc}$ & $279.9 \mathrm{~cd}$ & $5.59 \mathrm{~b}$ & 2.19 bc \\
\hline & $\mathrm{N}_{2} \mathrm{P}_{1}$ & $63.5 \mathrm{a}$ & 12.1 bc & $277.4 \mathrm{~cd}$ & $5.58 \mathrm{~b}$ & 2.18 bc \\
\hline & $\mathrm{N}_{2} \mathrm{P}_{2}$ & $62.1 \mathrm{ab}$ & $13.3 \mathrm{~b}$ & 271.7 de & $5.67 \mathrm{~b}$ & 2.15 bc \\
\hline & $\mathrm{N}_{2} \mathrm{P}_{3}$ & 59.9 abc & $13.4 \mathrm{~b}$ & 28.2 c & $5.58 \mathrm{~b}$ & 2.17 bc \\
\hline & $\mathrm{N}_{3} \mathrm{P}_{1}$ & 60.4 abc & $13.3 \mathrm{~b}$ & $287.1 \mathrm{c}$ & $5.39 \mathrm{~cd}$ & 2.17 bc \\
\hline & $\mathrm{N}_{3} \mathrm{P}_{2}$ & 60.5 abc & $13.7 \mathrm{ab}$ & 288.4 c & $5.38 \mathrm{~cd}$ & 2.15 bc \\
\hline & $\mathrm{N}_{3} \mathrm{P}_{3}$ & $60.0 \mathrm{abc}$ & $13.5 \mathrm{~b}$ & 285.2 c & $5.59 \mathrm{~b}$ & $2.16 \mathrm{bc}$ \\
\hline
\end{tabular}

* Means with the same letter are not different from one another at $5 \%$ level of significance. 
followed by $\mathrm{N}_{3} \mathrm{P}_{1}$. The minimum plant height was obtained from control treatment. The value was significantly lower than other treatments. The maximum head diameter was obtained from the plot receiving fertilizer at $\mathrm{N}_{3} \mathrm{P}_{2}$ treatment. The maximum number of seeds (339.8) per head was found with the application of $\mathrm{N}$ - P fertilizer at the rate of
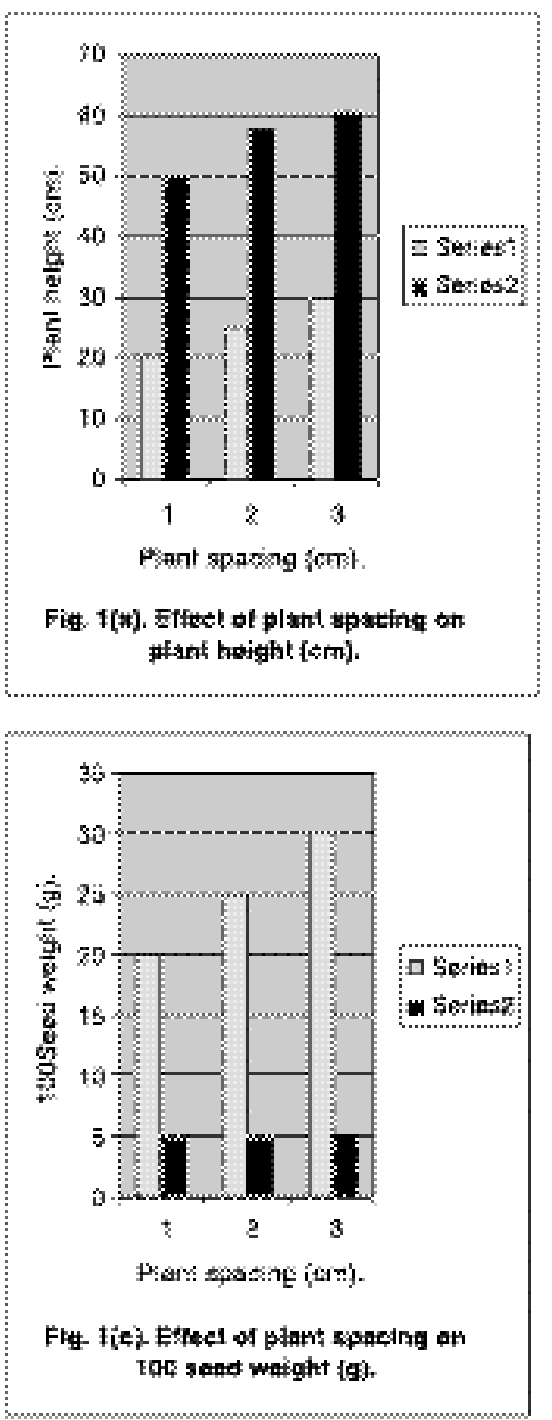

$\mathrm{N}_{120} \mathrm{P}_{75} \mathrm{~kg} / \mathrm{ha}$. The results were in close conformity with those of Nayak et al. who observed that the number of seeds per head in sunflower was increased progressively due to higher doses of nitrogen-phosphorus fertilizer application. ${ }^{19} 100$ seed weight of sunflower was found to vary from $5.01-5.73 \mathrm{~g}$. The plot which received fertilizer at the rate 120

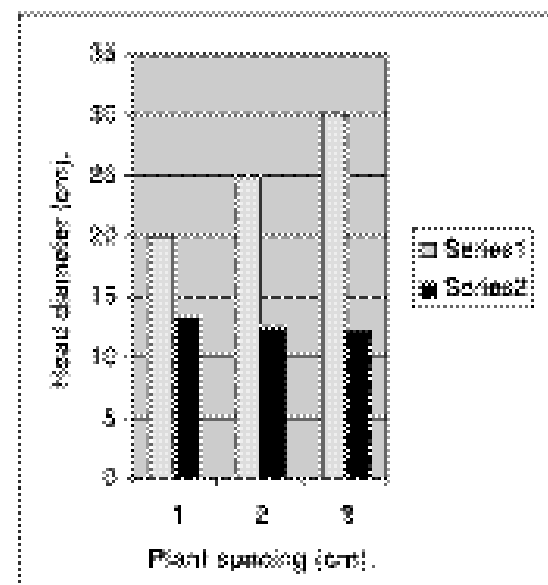

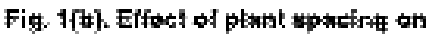

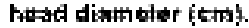

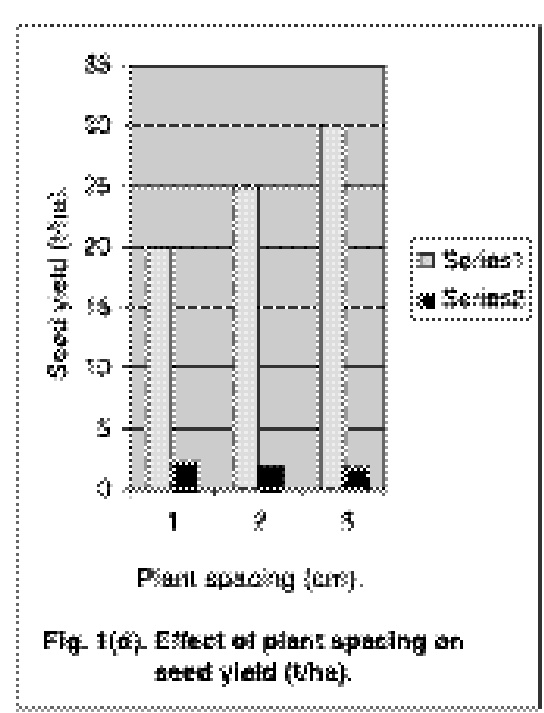



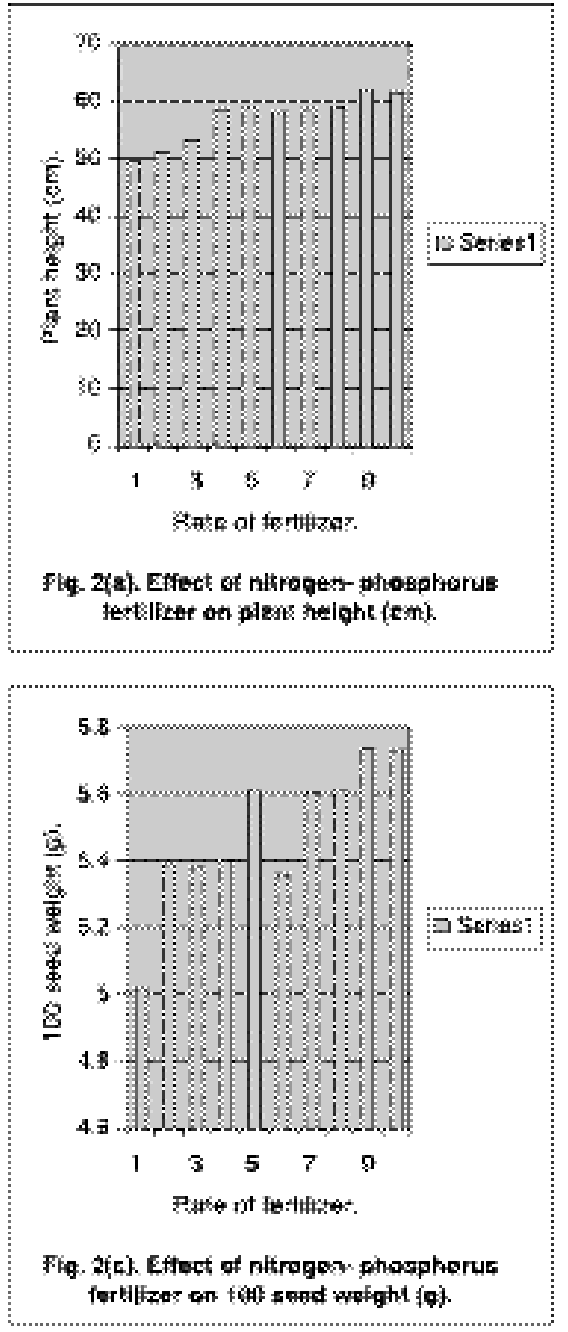

$\mathrm{kg} \mathrm{N}+75 \mathrm{~kg} \mathrm{P}_{2} \mathrm{O}_{5}$ per hectare produced the highest seed yield of $2.08 \mathrm{t} / \mathrm{ha}$. The results are in close agreement with the findings of Tomar et al. but disagreed with Tripathi et al. who found maximum seed yield of sunflower with lower dose of nitrogen (40 kg/ha) with conjugation of phosphorus. ${ }^{20-21}$

\section{Interaction Effect}

In the interaction effect of the fertilizer and plant spacing, the highest plant was produced
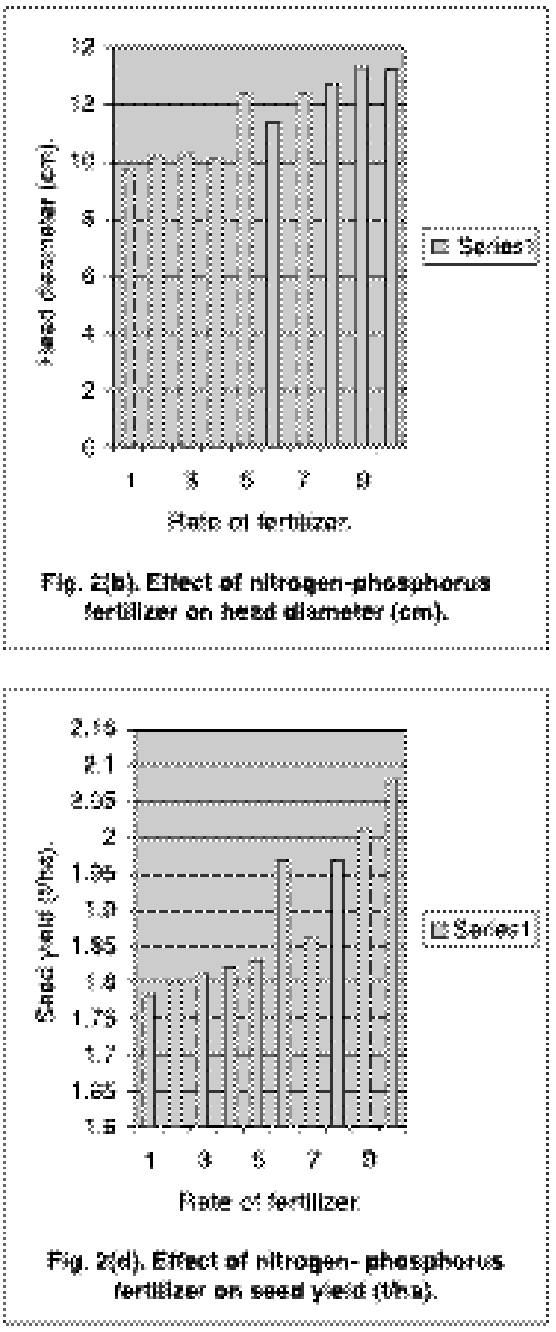

from the plot which was fertilized at the rate of $\mathrm{N}_{2} \mathrm{P}_{2}$ per hectare with plant spacing of 30 $\mathrm{cm}$. The second highest plant height was obtained from $\mathrm{N}_{2} \mathrm{P}_{2}$ and $\mathrm{N}_{3} \mathrm{P}_{3}$ treatments space at 30 and $25 \mathrm{~cm}$ plant spacing respectively. The value of head diameter per plant ranged from $11.8-14.5 \mathrm{~cm}$. The highest number of head diameter produced from $\mathrm{N}_{3} \mathrm{P}_{3}$ treatment with plant spacing of $20 \mathrm{~cm}$. The variation in the number of seeds varied 
from 340.9-265.2. Maximum number of seed (340.9) per head was obtained in combination with $\mathrm{N}_{3} \mathrm{P}_{2}$ treatment with $20 \mathrm{~cm}$ plant spacing. The findings were in close conformity with the result of Kene et al. who obtained the maximum number of seeds higher rate of $\mathrm{N}-\mathrm{P}$ application with closer plant spacing. ${ }^{22}$ The next number of seeds per head of the sunflower plant was obtained by $\mathrm{N}_{3} \mathrm{P}_{1}$ and $\mathrm{N}_{1} \mathrm{P}_{3}$ treatment with mean number of 340.1 and 339.1, respectively with same plant spacing. The maximum plot yield of seed was produced from the plot receiving fertilizer at the rate of $120 \mathrm{~kg} \mathrm{~N}+75 \mathrm{~kg} \mathrm{P}_{2} \mathrm{O}_{5}$ per hectare. The superiority of closer plant spacing with increasing nitrogen-phosphorus application in sunflower yield has been reported by Hedge et al. and Sharma et al. ${ }^{23-24}$ The next higher seed yield was obtained from $\mathrm{N}_{3} \mathrm{P}_{2}$ treatment.

\section{Conclusion}

The findings of the study indicate that the plant spacing and nitrogen-phosphorus fertilizer application treatment improved the yield contributing character efficiency of sunflower leading to higher seed yield. So, the further research is needed in this direction with other varieties of sunflower to establish the present findings.

\section{Acknowledgement}

The authors are grateful to the Director, BCSIR Laboratories, Dhaka for his interest during the progress of the work. They do acknowledgement the assistance rendered by
Mohammedullah Prodhan for the collection and preparation of plant sample.

\section{References}

1. FAO (Food and Agriculture Organization) Production Year Book. 37(70) (1985) 142-149.

2. M. A. Khaleque and M. M. S. Haque. Prospect of sunflower cultivation as an oil seed crop in Bangladesh. Krishi Katha. 52(9) (1993) 379-383.

3. R. G. Robinson, J. H. Ford, W. E. Luesches. D. L. Rabas, L. J. Smith, D. D. Warnes and J. V. Wiersma. Response of sunflower in plant population. Agronomy. J. 72 (1980) 869-871.

4. S. G. Reddy, V. Marathi, D. G. Rao and M. Vanaja. Effect of plant density and moisture stress on productivity of sunflower. Annals Agric. Res. 18(4) (1997) 482-487.

5. F. T. Villalobos,. V. O. Sadres, A. Soriano and E. Fereres. Planting density of dry matter partitioning and productivity of sunflower bybrides. Field crops Res. 36 (1984) 1-11.

6. K. V. G. Kharga and B. G. Nirwal. Effects of inter and intra spacing and nitrogen levels of sunflower. Agricultural Science Digest. 13(2) (1993) 115-116.

7. S. K. Sharma and B. K. Gaur. Effect of level and method of nitrogen application on seed yield and quality of sunflower. Ind. J. Agron. 33(3) (1988) 330-331. 
8. Vivck and I. S. Chakor. Effect of nitrogen and irrigation on growth and yield of sunflower under mid-hill condition of Himachal Pradesh. Ind. J. Agron. 37(7) (1992) 500-502.

9. N. J. Chariara, J. C. Patel. D. D. Malavia and N. M. Baidha. Effect of irrigation, nitrogen and phosphorus on the productivity of sunflower. Ind. J. Agron. 34(3) (1989) 399-401.

10. S. M. Singh and R. K. Pacheria. Effect of varying row spacing, nitrogen and phosphorus levels on sunflower. Ind. J. Agron 26(10) (1981) 20-23.

11. U. S. Ujjinaiah, N. R. Shahthamallaiah and N. M. Murali. Effect of different row spacing and $\mathrm{N}$ and $\mathrm{P}_{2} \mathrm{O}_{5}$ fertilizer levels on growth, yield components and quality of seeds in sunflower. Mysore J. Agri. Sci. 23(2) (1989) 146-150.

12. M. L. Jacson. Soil chemical analysis. (1962). Constabel and Co. Ltd. London.

13. S. Walksman. Cybele and Britannica. 4 (1936) 379.

14. R. G. D. Steel and J. H. Torrie. Principles and Procedures of Statistics. McGraw Hill Book Co. Inc. New York. (1960) 109.

15. A. Bindra and P. C. Kharware. Response of sunflower to nitrogen application and spacing. Ind. J. Agron. 32(2) (1992) 283-284.

16. N. Islam, M. A. Kader and M. Z. Islam. Response of hybrid and local varietities of sunflower to spacing and fertilizer levels.
Bang. J. Agri Sci. 27(1) (2000) 19-23.

17. E. Zaffaroni and A. A. Schneiter. Sunflower production as influenced by plant type, plant population and row arrangement. Agronomy J. 83(1) (1991) 113-118.

18. S. V. C. Rao and G. Saran, Response of sunflower cultivars to planting density and nutrient application. Ind. J. Agron. 36(1) (1991) 95-98.

19. B. C. Nayak and P. K. Ghosh. Response of sunflower varieties to $\mathrm{N}$ and P. Orissa. $J$. Agri. Res. 3(3-4) (1990) 252-61.

20. H. P. S. Tomar, H. P. Singh and K. S. Dadhwal. Effectof irrigation, nitrogen and phosphorus on growth and yield of spring sunflower. Ind. J. Agron. 42(1) (1997) 169-172.

21. P. K. Tripathi and G. S. Kalra. Effect of NPK on Maturity and yield of sunflower. Ind. J. Agron. 26(1) (1980) 66-70.

22. H. K. Kene, V. R. Thosar, R. B. Ulemale and M. R. Kale. Response of sunflower to spacing and nitrogen, phophorus fertilizer. J. Maharashtra Agri. Uni. 17(3) (1992) 433-35.

23. M. R. Hedge and G. V. Havanagi. Effect of plant population and fertility levels on the growth and yield of sunflower. J. Oil Seeds Res. 4 (1987) 185-192.

24. P. C. Sharma, S. K. Katyal and O. P. S. Verma. Growth and yield of sunflower varieties in relation to fertility level and plant population. Ind. J. Agron. 37(2) (1992) 285-289. 